
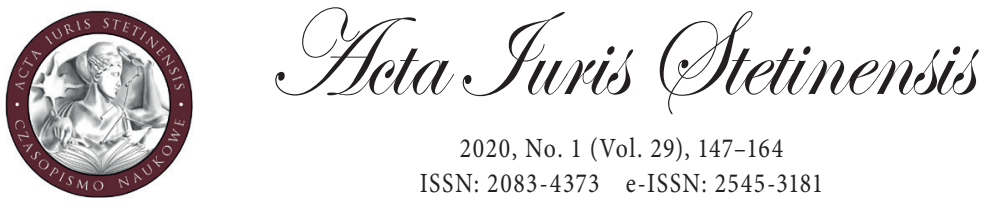

2020, No. 1 (Vol. 29), 147-164

ISSN: 2083-4373 e-ISSN: 2545-3181

DOI: $10.18276 /$ ais.2020.29-10

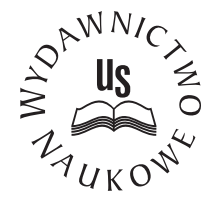

Mateusz Podhalicz

Ph.D. student

University of Lodz, Poland

Faculty of Law and Administration

e-mail: mateusz.podhalicz@edu.uni.lodz.pl

open Access

ORCID ID: 0000-0002-0605-2050

\title{
Protecting the right to clean air through criminal law: a perspective from economic law analysis and the case of Poland
}

\begin{abstract}
The aim of this paper is to examine whether Polish criminal law efficiently criminalises acts that harm air quality (most notably emissions of toxins to the air through, among others, the improper processing of waste). The relevance of this research stems from the notorious fact that air-quality in Poland is one of the worst in Europe, and it is no secret that this situation is caused largely by private actors infringing on rules concerning the emissions of toxins into the environment. As the author establishes through legal analysis, the collection of empirical data, and on the basis of an economic-law-analysis crime model, Polish criminal law fails thoroughly when it comes to combatting this phenomenon. Relating the current legal regulations and, most importantly, their employment in practice to the prerequisites of effective crime policy (as envisaged by G. Becker), it is doubtless that for the poor air-quality in Poland to change, the state should aim at reaching a better detection rate when it comes to environmental crimes, as well as inflicting more severe penalties on the perpetrators of those crimes. This, coupled with proper educational campaigns directed at citizens and law enforcement authorities at large, should bring about higher levels of deterrence when it comes to these crimes, and by extension, enhance air quality in Poland.
\end{abstract}

Keywords: air pollution, efficiency of environmental criminal law, right to a clean environment, economic law analysis 


\section{Introduction}

In a situation when legal goods are not sufficiently protected by civil law, or when their protection is a public matter, it should be regulated through administrative or penal law (or both). ${ }^{1}$ That statement perfectly applies to protecting the environment and, among other things, ensuring clean air quality. It is agreed in the legal scholarship and commentary that in cases of a violation of environmental norms, a suitable public law regulation is necessary to scare off potential violators and minimise the negative externalities generated by their acts. The reasons for that are manifold. First, it is quite complicated for private entities to detect those who have violated their rights with respect to a clean environment. Such a private actor does not have the organisational or legal instruments that are at the public authorities' disposal. ${ }^{2}$ Moreover, it is not insignificant that the effects of emissions are dispersed, which means that the group of victims may be very difficult to determine. ${ }^{3}$ Finally, considering this matter from an economic-law-analysis standpoint, it must be stressed that if a wrongful act is only regulated in civil law, it means no less than that the legislator allows the commission of such an act provided that the perpetrator is ready to pay restitution (an amount equal to the damage caused). On the other hand, criminalisation makes clear that the lawmaker's intent is to fully prohibit a wrongful act due to its destructive and anti-social nature. ${ }^{4}$ In that case, it is not necessary, and most often not advisable, to set the legal penalty as equal to the damage, rather the punishment should deter the perpetrator.

This paper will discuss how well criminal law provides for such deterrence. It will analyse whether the criminal code and other acts properly criminalise the actions of citizens that harm air quality at large. The importance of this research cannot be overstated. It is a notorious fact that air quality in Poland is one of the worst in Europe, and it is no secret whatsoever that this situation is caused largely by private actors, namely people and entities emitting toxins into the air through the use of poor-quality fuel to heat their homes. Among the most detrimental practices of

1 Cooter, R. and Ulen, T., Law and economics, $6^{\text {th }}$ edition, Berkeley 2016, pp. 460-461.

2 Posner, R., An economic theory of the criminal law, "Columbia Law Review" 1985, No. 85, pp. 1193 209; Skogh, G., A note on Gary Becker's crime and punishment: an economic approach, "Swedish Journal of Economics" 1973, Vol. 75, pp. 305-311; Skogh, G. and Stuart, C., An economic analysis of crime rates, punishment and the social consequences of crime, "Public Choice" 1982, No. 38, pp. 171-179.

3 Faure, M., Environmental crimes, in: Garoupa, N. (ed.), Criminal law and economics, Cheltenham 2009, pp. 320-345.

4 Cooter, R., Prices and sanctions, “Columbia Law Review” 1984, No. 6, p. 1550. 
this kind one can name is the illegal incineration of waste, which leads to emitting carcinogenic aromatic hydrocarbons (most notably benzopyrene).

Next to formal legal analysis, this paper draws upon such interpretation methods as comparative analysis, as well as economic law analysis, which provides an invaluable framework to assess the legal regulations from viability and cost-efficiency standpoints.

At this point, it might be asked whether criminal regulation is at all necessary to regulate air-polluting activities. It could be posited that administrative regulation would be more suited to tackle this problem. In economic-law-analysis literature, it is strongly advised that imposing small penalties for 'less significant crimes' within criminal procedure is far more costly and less efficient than doing so through administrative law (which is partly because of the fewer procedural guarantees in the latter type of proceedings ${ }^{5}$ ).

To counter it, it can be said that because the probability of detection of air pollution is relatively low, the penalties for such acts should be that much higher (more on that later). Quite obviously, administrative law is arguably not the optimal medium for imposing high financial penalties, and surely not punishment consisting of deprivation or limitation of liberty ${ }^{6}$. Moreover, such penalties are not possible to use as substitutes in administrative law, although such a possibility exists within criminal law. Because of that, administrative law might prove fully inefficient towards a person who does not have any means to cover the financial penalty imposed on him. This may very often be the case when it comes to air pollution and the generation of particulate matter since the overarching reason for such behaviour is very often poverty and such people's poor financial circumstances. Taking all of the above into account, it seems reasonable to claim that in order to achieve the desired level of prevention of the described illegal acts, criminal regulation is necessary, even if serving as a complement to existing administrative measures.

\section{Criminalisation of acts against the environment}

The Polish Criminal Code ${ }^{7}$ provides two types of crimes that can apply to those who emit air-polluting substances. They are regulated, respectively, in Arts. 182 and 183 CC, i.e., in chapter XXII of the Code dedicated to crimes against the environment.

5 Ogus, A. and Abbot, C., Pollution and penalties, in: Swanson, T. (ed.), An introduction to the law and economics of environmental policy: issues in institutional design, Amsterdam 2002, pp. 493-516.

6 Miceli T., Optimal prosecution of defendants whose guilt is uncertain, "Journal of Law, Economics and Organisation" 1990, No. 6, pp. 189-201.

7 Act of 6 June 1997 - Criminal Code, Dz.U. (Journal of Laws) 2018, item 1600 (hereinafter: CC). 
In order to determine whether the above-mentioned legal provisions can be useful when battling polluting the atmosphere, their components need to be described. Then it will be necessary to ascertain whether actions such as the incineration of waste, use of heating devices of poor quality, or overall excessive emission of pollution can be qualified as one of those crimes. When interpreting those provisions, the question of how they are put into practice by judicial authorities will be taken into account.

\section{Pollution of the environment - Art. $182 \$ 1$ CC}

Art. $182 \S 1$ CC penalises the behaviour of a person who pollutes the air with a substance or radiation in such quantities or form that could pose a danger to the life or health of many people, or cause significant destruction of plant and animal life. The crime may be committed intentionally, in which case it is punishable by imprisonment for three months to five years, or unintentionally (182\$2 CC), in which case it is punishable with a fine, restriction of liberty, or imprisonment for up to two years.

Moving to the analysis of each component of the crime, it should first be noted that the existence of this crime requires that the criminal has polluted the air. The Criminal Code does not define that act, which is why, by virtue of systemic interpretation, we should turn to its definition under Art. 3, point 49 in conjunction with point $3 \mathrm{EPL} .{ }^{8}$ This provision stipulates that air pollution should be understood as introducing substances into the air directly or indirectly, which may deteriorate the aesthetic qualities of the environment or interfere with other justified uses thereof. Given that pollution consists of introducing substances, it follows that it can only be committed by action, and not by omission (unless there is a specific obligation on the offender to prevent such pollution ${ }^{9}$ ).

In that respect, it is doubtless that actions such as incinerating waste and producing toxic gaseous substances and particulate matter, as well as the use of low-quality heating devices, can be deemed as air pollution within the meaning of Art. $182 \$ 1$ CC, as they generate PM10 and PM2.5 particles as well as benzopyrene, and introduce them into the atmosphere.

The next component necessary to commit the described crime is that the criminal's action should bring about consequences in the form of creating a threat of pollution of a certain degree and intensity. The threatening pollution needs to be

8 Act of 27 April 2001 - Environmental Protection Law (hereinafter: EPL), Dz.U. (Journal of Laws) 2018, pp. 799.

9 Lachowski, J., Komentarz do art. 182 CC, in: Konarska-Wrzosek, V. (ed.), Kodeks karny. Komentarz, 2018, LEX. 
high enough for it to compromise human life or health, or the quality of air, or plant and animal life. What is crucial is that these consequences do not actually have to come about. It is just enough that such an occurrence is probable. ${ }^{10}$ It is also not necessary for the pollution to compromise the health of more than one person. ${ }^{11}$ In other words, the described crime is that of an abstract-concrete exposure to danger. ${ }^{12}$ Thus, the crime has a material character, unlike the one indicated by legal scholar and commentators, ${ }^{13}$ as it requires an effect to take place.

It also needs to be stressed that the action of one person may already create such a threat, which is required in order for the crime to exist. To argue otherwise would lead to the virtual impossibility of employing the provision in the described way, which would definitely be counterproductive. ${ }^{14}$ It is true that such a conclusion departs from the strict obligation typical in cases of criminal law to establish a causal link between the action and the effect. However, sticking to that in the case of Art. $182 \S 1$ CC would neglect the specific nature of the crime against the environment and the pure impossibility of establishing a strict causal link between a particular emission in question and threat to life. In the author's view, it is fully sufficient that the action of one person consisting of air pollution increases the threat to life in order to ascribe criminal responsibility under Art. $182 \$ 1 \mathrm{CC}$. Such a conclusion, it seems, does not contravene the Constitution and its Art. 42, which requires that criminal responsibility be possible to be accurately determined and which prohibits broadening the interpretation of provisions. There is no broadening, since the action of one person who produces pollution, especially when committed continuously throughout the heating season, already creates a risk of deteriorating human health, and thus fulfils the necessary conditions under Art. $182 \S 1$ CC. ${ }^{15}$

However one may perceive that the above-mentioned problem of the attributability of the effect to the actions of one person should at least be verified through standard criminal procedure. It is obvious since the emission of harmful pollution

10 Radecki, W., Ochrona środowiska w nowym prawie karnym, cz. II: Prawnokarna ochrona przed zanieczyszczeniami, odpadami i promieniowaniem, "Monitor Prawniczy" 1998, No. 1, Legalis.

11 Similarly: Gałązka, M., Komentarz do art. 182, in: Grześkowiak, A. and Wiak, K. (eds.), Kodeks karny. Komentarz, Warszawa 2019; it was different before the revision of March 2011 when it was necessary that the threat concerned multiple people. Cf: Radecki, W., Komentarz do art. 182 k.k. in: Górniok, O. (ed.), Kodeks karny. Komentarz, Warszawa 2005.

12 In the sense that the pollution has to be real and the danger connected with it potential/abstract.

13 Gruszecka, D., Komentarz do art. 182, in: Giezek, J. (ed.) Kodeks karny. Czesść szczególna. Komentarz, Warszawa 2014, p. 425; Zoll, A., Komentarz do art. 182, in: Wróbel, W. and Zoll, A. (eds.), Kodeks karny. Część ogólna. Tom I. Część I. Komentarz do art. 1-52, 2016, LEX, paragraph 3.

14 Radecki, W., Ochrona..., op. cit., Legalis.

15 Similarly, Judgement of the Appellate Court in Wrocław of 21 September 2017, II AKa 236/17, LEX no. 2381444. 
already creates a suspicion of committing a crime under Art. 182 CC, which means that the existence of its elements should be verified through evidentiary proceedings before at least a prosecutor in criminal preparatory proceedings (pursuant to Art. $303 \mathrm{CPC}$ in conjunction with Art. 325a $\$ 2 \mathrm{CPC}^{16}$ ). In such proceedings, calling upon an expert should be considered in order to establish what threat to human life was generated by the offender's actions. This, however, for unknown reasons, almost never happens. Cases concerning Art. 182 CC are rarely opened, and the conviction rate is remarkably low (see below).

Table 1. Data concerning the number of cases related to Art. $182 \S 1$ CC

\begin{tabular}{|c|c|c|c|c|}
\hline Year & $\begin{array}{c}\text { Number } \\
\text { of cases opened }\end{array}$ & $\begin{array}{c}\text { Number } \\
\text { of convictions }\end{array}$ & Crimes detected & $\begin{array}{c}\text { Detection rate } \\
\text { (in \%) }\end{array}$ \\
\hline 2017 & 111 & 22 & 7 & 31.8 \\
\hline 2016 & 109 & 19 & 9 & 47.4 \\
\hline 2015 & 100 & 16 & 2 & 37.5 \\
\hline 2014 & 91 & 14 & 7 & 14.3 \\
\hline 2013 & 99 & 24 & 4 & 29.2 \\
\hline 2012 & 95 & 8 & 0 & 50.0 \\
\hline 2011 & 60 & 6 & 5 & 0.0 \\
\hline 2010 & 68 & 12 & 5 & 41.7 \\
\hline 2009 & 107 & 14 & 5 & 35.7 \\
\hline 2008 & 16 & 6 & 31.3 \\
\hline
\end{tabular}

Source: http://statystyka.policja.pl/st/kodeks-karny/przestepstwa-przeciwko-3/63472, Zanieczyszczanie-srodowiska-art-182.html (accessed 15.02.2020).

The final component of corpus delicti of the crime in question is intent. As mentioned above, this particular crime may be committed both intentionally and unintentionally. To perceive any criminal act as an intentional one, there are two possible scenarios. Either the perpetrator has to both want (direct intent) to commit a crime along with all of its objective components (in the case of the act described in Art. $182 \$ 1 \mathrm{CC}$, the perpetrator has to be willing to engender pollution of such an intense degree that it creates a risk to human life or health, or the quality of air, or plant and animal life). ${ }^{17}$ Alternatively, a perpetrator of such an act has to realise and accept that his/her actions may bring about such dangerous pollution, without it being their goal (possible intent). In all other cases, committing a crime described

16 Act of 6 June 1997 - Criminal Proceedings Code, Dz.U. (Journal of Laws) 2018, item 1987.

17 Zoll, A., op.cit. 
in Art. $182 \$ 1 \mathrm{CC}$ would have to be considered as unintentional and thus punishable on the basis of $\$ 3$ of this provision.

Naturally, in cases of this criminal act and environmental crimes in general, proving intent is rather a daunting challenge. Given that most people do not want to create pollution for the sake of it, as a rule their possible intent would have to be considered. To prove that, however, it would have to be demonstrated beyond reasonable doubt that a perpetrator of this act had knowledge and awareness that his/her actions, (coupled with other polluters) may in turn give rise to dangerous consequences, notably to human life and health. It seems to the author that, as the social awareness of these issues is increasing, it will be possible to assume that it is general knowledge that unlawful emissions of pollution may be detrimental to public health and the environment. On the other hand, such an assumption could and would undoubtedly be challenged by the perpetrator in the course of criminal proceedings, and there is little doubt it would have to be resolved in his/her favour. ${ }^{18}$ Notwithstanding, the legislator provides that a crime fulfilling the objective elements envisaged in Art. $182 \$ 1 \mathrm{CC}$ may also by committed without intent, that is to say, not in a careful manner required under the circumstances, when the possibility of committing the prohibited act should or could have been foreseen. While in cases of unlawful dangerous emissions existence of possible intent may at times be difficult to prove, there should be no difficulty in establishing that it is common knowledge that emitting substances into the atmosphere requires care concerning such key aspects as the chemical nature of the released toxins and potential hazardous consequences thereof. From that standpoint, it seems that the question of intent of committing the crime envisaged in Art. $183 \$ 1 \mathrm{CC}$ is not that relevant as regards the attributability of the crime itself, since it is rather improbable that a person accused of committing the crime in question could successfully prove they lacked acting with due care while performing unlawful emissions of toxic substances into the air.

To conclude, it has to be said that even though the above-described provision could technically be an efficient instrument against those who insist on polluting the atmosphere in a continuous fashion, it is regrettably not at all employed in that way. As will be shown below, criminals have to be sufficiently deterred in order for criminal law to work. If the above provision is not used, even though it could be, what is left is prosecuting offenders on the grounds of minor delinquency, which means that the offenders face very limited charges, and in turn, that the rate of deterrence may be too low.

18 Kurowski, M., Komentarz do art. 5, in: Świecki, D. (ed.), Kodeks postępowania karnego. Tom I. Komentarz, 2020, LEX. 
Improper waste management - Art. $183 \$ 1 \mathrm{CC}$ and Art. 155 of the Waste Act ${ }^{19}$

Art. $183 \$ 1$ CC penalises behaviour in which the offender, in violation of the law, stores, disposes of, recycles, neutralises or transports waste or substances under conditions or in a manner that could pose a danger to the life or health of human beings, or cause significant destruction to plant or animal life, and is liable to imprisonment for between three months and five years. As can be seen at first glance, this provision may be useful in battling the harmful behaviours to which this article refers. The above-mentioned crime, just like the one from Art. $182 \$ 1$ $\mathrm{CC}$, can be committed intentionally or unintentionally.

Referring first to the object of the criminal act, it is waste, as defined in the Waste Act, i.e., as each substance or object whose possessor disposes of or intends or is obliged to dispose of. ${ }^{20}$ For the object to be considered waste, it is unimportant whether after its possessor disposes of it, someone may find it and put it to some use. ${ }^{21}$

As regards the action that the crime may consist of, considering the topic of the article, it is the processing of waste, its recycling and neutralisation. It is doubtless that incineration of waste is one of those actions, and thus falls under the scope of Art. $183 \$ 1$ CC.

A person commits the crime described in that article only when their actions towards waste are 'in violation of the law', that is, they contravene respective administrative provisions regarding waste management. It needs to be indicated that neither of the above provisions allows the incineration of waste at home, and thus such behaviour will always be in violation of the law, and fulfils the described component of Art. $183 \$ 1 \mathrm{CC}$.

For the existence of a crime under Art. $183 \$ 1 \mathrm{CC}$, it is also necessary - not unlike in the case of Art. $182 \$ 1 \mathrm{CC}$ - that unlawful management of waste described in the provision should bring about consequences in the form of creating a threat of pollution of a certain degree and intensity. The threatening pollution needs to be high enough for it to compromise human life or health, or the quality of air, or plant and animal life. As this component is identical to the one in Art. $182 \$ 1 \mathrm{CC}$, it is sufficient to state that all of the considerations applying to that crime are also valid in the case of Art. $183 \$ 1 \mathrm{CC}$.

19 Act of 14 December 2012 on waste, Dz.U. (Journal of Laws) 2018, item 992. (hereinafter: Waste Act).

20 Królikowski, M., Komentarz do art. 183, in: Królikowski, M. and Zawłocki, R. (eds.), Kodeks karny. Część szczególna. Tom I. Komentarz do artykutów 117-221, 2017, Legalis.

21 Judgement of the Regional Administrative Court in Warsaw of 21 September 2010, IV SA/Wa 868/10, Legalis 279206 . 
From this short analysis, it follows that the behaviour being the focal point of this section, i.e., the incineration of waste, which produces much of smog's most dangerous chemical components (most notably the cancerogenic benzopyrene), is criminalised by Art. $183 \$ 1 \mathrm{CC}$. Just as in the case of Art. $182 \$ 1 \mathrm{CC}$, although the judicial organs know about the widespread practice of incinerating waste, offenders are not persecuted, and if they are, it is on the basis of minor offences and not according to Art. $183 \$ 1 \mathrm{CC}$. The rarity, and consequently, the fallacy of the employment of this provision is manifest, considering the low number of convictions based on it. By way of example, in 2017 only 51 violations of this provision were legally confirmed. This number remains in stark contrast with simple human experience, which tells us that each day there is at least one person in our neighbourhood who perpetrates such an act. Instead of prosecuting them, law enforcement is content with considering those acts as merely minor offences.

Table 2. Data concerning the number of cases regarding Art. $182 \$ 1$ CC

\begin{tabular}{|c|c|c|c|c|}
\hline Year & $\begin{array}{c}\text { Number } \\
\text { of cases opened }\end{array}$ & $\begin{array}{c}\text { Number } \\
\text { of convictions }\end{array}$ & Crimes detected & $\begin{array}{c}\text { Detection rate } \\
\text { (in \%) }\end{array}$ \\
\hline 2017 & 249 & 51 & 28 & 54.9 \\
\hline 2016 & 224 & 48 & 32 & 65.3 \\
\hline 2015 & 175 & 43 & 31 & 72.1 \\
\hline 2014 & 172 & 56 & 32 & 57.1 \\
\hline 2013 & 150 & 75 & 23 & 70.7 \\
\hline 2012 & 172 & 42 & 26 & 53.5 \\
\hline 2011 & 99 & 35 & 36 & 74.3 \\
\hline 2010 & 191 & 52 & 55 & 69.2 \\
\hline 2009 & 162 & 69 & 62 & 79.7 \\
\hline 2008 & 209 & 80 & 73.5 \\
\hline
\end{tabular}

Source: http://statystyka.policja.pl/st/kodeks-karny/przestepstwa-przeciwko-3/63476,Nieodpowiedniepostepowanie-z-odpadami-art-183.html (accessed 15.02.2020).

A complementary regulation to the one described above is Art. 191 of the Waste Act. This article provides that it is illegal to incinerate waste outside of authorised waste-treatment facilities. Unlike the act criminalised by Art. $183 \$ 1 \mathrm{CC}$, this act is not a crime but a minor offence, punishable by a maximum fine of PLN 5,000 or detention for a maximum of 30 days. It can be perpetrated by a physical person, and responsibility for such an act does not depend on the consequences that it 
could bring (such as danger to life or health), which marks a radical difference in comparison with the crime of waste mismanagement.

Assessment of this regulation is not an easy task. On one hand, this regulation perfectly complements the more stringent one provided in Art. $183 \$ 1$ CC so that someone who does burn their waste can be held liable, even if it did not bring about the consequences necessary to pursue such a person on the grounds of Art. 183 $\$ 1 \mathrm{CC}$. In that sense, the regulation has to be praised. On the other hand, it also leads law enforcement authorities to choose to pursue detected perpetrators on the grounds of the Waste Act rather than to tackle the more complicated task of building a convincing case based on Art. $183 \$ 1 \mathrm{CC}$, even if it better fits the committed offence. Thus, the existence of less-severe criminal responsibility in the form of Art. 191 of the Waste Act may in fact hinder the proper use of Art. $183 \$ 1$ CC. It has to be noted that if someone constantly commits the described minor offence, they will inevitably in total create enough toxic emissions that will engender a risk to the life and health of people. This, in turn, fulfils the condition necessary to prosecute such a person on the grounds of the Criminal Code (and with far stricter penalties possible). ${ }^{22}$ However, this has never been acknowledged or recognized by Polish law-enforcement authorities, which content themselves with simply punishing offenders for the minor offence provided in Art. 191 of the Waste Act, even in cases when these people commit the offence of the illegal incineration of waste on a regular basis.

Such a practice is downright unacceptable. It means that in practice, people guilty of regular emissions - and by that same token, of emitting considerable amounts of toxic gases - may face only a small fine or a short stay in jail. The exact consequences of such a deplorable oversight on the part of law enforcers will be discussed in the next part of the paper.

\section{The adequacy and efficiency of the Polish criminal regulation devised to protect the environment}

The next question that needs to be asked is about the character of the penal regulations concerning air pollution, as well as their scope, practice of implementation, severity, and finally, whether they form with other legal norms a cohesive system of protection of the air and its users. In the following sections, I will analyse the methodology of such an assessment and then make an attempt to apply that methodology to the above-described criminal regulations. On the grounds of the

22 Radecki, W., Komentarz do art. 191, in: Radecki, W. (ed.), Ustawa o odpadach. Komentarz, Warszawa 2020, LEX. 
proposed assessment model, those regulations will be critically assessed as regards their functionality, efficiency, and possible ways of improvement.

\section{Becker Model - methodology of assessment}

The efficiency of criminal law should, in brief, be considered as its capability to discourage legal entities from committing crimes. This notion has always been a subject of interest among philosophers and legal theorists, primarily of philosopher Jeremy Bentham. ${ }^{23}$ The modern methodology of criminal law efficiency was formulated by economist and Nobel Prize winner in economics G. Becker in his article Crime and punishment: an economic approach. ${ }^{24}$ The Becker model gives the answer to what kinds of punishments should be imposed on criminals for given crimes, how severe those punishments should be, and finally what is the optimal rate of detection of the analysed crimes in order to minimise negative externalities resulting from the commission of crimes of this type (where the externalities comprise damage resulting from crimes, the costs of detection and conviction of offenders, as well as the costs of their punishment). Efficient criminal law minimises such negative externalities. As a matter of fact, the more severe the externalities of certain crimes are, the more it is beneficial to invest in detecting them or to increasing the punishment for perpetrating them.

In his analysis, Becker assumed that a criminal acts rationally, i.e., they want to maximise gain from crimes. Thus, their decision as to whether to commit crimes is a direct result of comparing the pros and cons of that decision. If the negative consequences of potential legal sanctions, considering the probability of detection, are equal to or higher than the expected gains, then they should decide against committing a crime. It needs to be said that the specific decision is dependent on the criminal's attitude to risk. ${ }^{25}$ From those considerations, it follows that the function

23 Bentham, J., Introduction to the principles of morals and legislation, Kitchener 2000, pp. 135-151, https://socialsciencepp.mcmaster.ca/econ/ugcm/3ll3/bentham/moralpp.pdf, (accessed 7.03.2019); Posner R., Frontiers of legal theory, Harvard 2004, p. 52.

24 Becker, G.S., Crime and punishment: an economic approach, "Journal of Political Economy”, Vol. 76, No. 2, pp. 169-217; Becker, G.S., Irrational behaviour and economic theory, "Journal of Political Economy" 1962, Vol. 70, pp. 1-13; Stigler G., The optimum enforcement of laws, "Journal of Political Economy" 1970, Vol. 78, No. 3, pp. 526-536.

25 And thus a risk-taking person will commit a crime even if the gain is marginal; on the other hand, a risk-averse person will resign from considerable gain in order to commit themselves to legal activities; Becker, G.S., Crime..., p. 176; Jajuga, W., in: Jajuga, W. (ed.), Zarządzanie ryzykiem, Warszawa 2007, p. 14. 
of criminal law is increasing the costs of committing crimes so that it is no longer beneficial to the criminal. ${ }^{26}$

According to the author, the instruments through which the state aims at achieving that goal is either increasing maximal sanctions for committing crimes or using more resources for detecting and sentencing criminals. Those instruments should interplay, and it is for the lawmaker to decide which is more important in any given situation. The same level of deterrence can be achieved by imposing draconian punishments and ensuring a very low detection rate. Conversely, lawmakers may opt for imposing very lenient penalties while ensuring that that the offenders will almost certainly be apprehended and convicted. The decision about what to do should always consider the costs of each alternative. The above-described conclusions, citing M. Polinsky and S. Shavell, ${ }^{27}$ can be approached in a more formal fashion:

where:

$$
P_{1}>0<=>Z_{P 1}>p(g+d(t))
$$

$P_{1}$ - supply of a specific crime

$Z_{P 1 \text { - gain from committing a crime }}$

$p$ - probability of detection

$g$ - usually imposed fines for the crime in question

$d(t)$ - disutility for the criminal arising from limiting or depriving their liberty.

The cost of committing crimes is expressed by the equation $p(g+d(t))$. That cost is in simple terms, the sum of criminal sanctions relative to the probability of detection and conviction of the criminal. In other words, if for a specific crime the typical punishment imposed is two years of imprisonment and the probability of detection and conviction is $50 \%$, the expected average cost of committing a crime is equal to the value that one year of imprisonment represents to the criminal. This value is naturally subjective and different for everyone. It depends on how much the criminal could earn during that time and also on extra-financial aspects, such as the family situation of the criminal or fear of losing his/her reputation. ${ }^{28}$

Naturally, it is much easier to determine the potential costs of committing a crime if the only possible penalty is a fine. In that case, the cost is the amount of the fine typically imposed times the probability of it being imposed. Because using this penalty, provided that it is successfully executed, generates no costs for

26 Bowles, R., Law and the economy, Oxford 1982, pp. 54-105.

27 Polinsky, M. and Shavell, P., The economic theory of public enforcement of law, "Journal of Economic Literature" 2000, No. 38, pp. 45-76.

28 Ashraf, N. et al., Adam Smith. Behavioral economist, "Journal of Economic Perspective" 2005, Vol. 19, No. 3, pp. 131-145. 
the state, it is economically speaking an optimal sanction. ${ }^{29}$ It is often an adequate price paid by the offender to the injured society, without making that society pay for executing the punishment (which is quite different in case of deprivation or limitation of liberty).

However, it has to be noted that fines are not always perfect sanctions. ${ }^{30}$ First, because of the fact that some offenders are insolvent, which renders financial fines quite ineffective, which finally will either be cancelled or exchanged for a different penalty.

Second, at times the deterrent power of fines may prove insufficient. As results from the Becker model, the state can check the interplay of two factors when deciding criminal policy: the severity of crimes and probability of detection. In some situations it may prove optimal to lower the detection rate and increase penalties. This is the case especially when crime detection is costly and difficult; in order to keep the deterrence unchanged, the state may limit its efforts in detecting crimes while increasing the severity of sanctions ${ }^{31}$. Given a certain low probability of detection, it may happen that even the highest fine possible will not be sufficient to successfully deter criminals from committing crimes, which in turn will mean that it will be necessary to resort to more severe charges.

Irrespective of the above, generally it has to be said that the above-cited authors are correct in saying that fines are usually optimal, especially when it comes to economic crimes (i.e., crimes in which the main motive is financial gain). On the one hand, such a penalty is just because it is directed against the assets of the criminal, who wanted to increase them through criminal means. On the other hand, society will not in such a case suffer the costs arising from executing the penalties (this philosophy is also adopted in the criminal code in Art. 57 CC).

29 Posner, R., Optimal sentences for white-collar criminals, "American Criminal Law Review" 1980, Vol. 17, pp. 400-418.

30 Coffee, J.P., Corporate crime and punishment: a non-Chicago view of the economics of criminal sanctions, "American Criminal Law Review" 1980, pp. 419-476; Shavell, P., Criminal law and the optimal use of non-monetary sanctions as a deterrent, "Columbia Law Review" 1985, No. 85, pp. 1232-1262.

31 See: Becker, S., Crime..., p. 183. 
The economic model in the case of environmental crimes

The model presented above also applies to environmental crimes directed against the quality of air, as described in the article $e^{32}$. It is said in the literature that in the case of such crimes, the penalties for committing them were not set properly in modern legal systems, as the costs of crime are lower than the gains the criminal reaps and the damages those crimes generate. Given that, it is claimed that the current deterrence level in the case of the described crimes is far too low. This conclusion is highly supported by the Becker Model and fully applies to Polish criminal law in that respect.

According to Becker, the more negative externalities a crime generates, the more severe the criminalisation should be. Despite that, environmental crimes, exponentially harmful as they are, do not seem to be prosecuted in Poland as a matter of priority. Quite the contrary - it seems that the fight against environmental crimes is rather lackadaisical.

Some authors do indicate that one of the reasons for it might be the sheer difficulty in detecting such crimes, their perpetrators, and consequences. ${ }^{33}$ The reason for this is quite simple. The described crimes are very common and, at the same time, they can happen in the privacy of each perpetrator's home. Once committed, the commission of the act may only be proven by costly and lengthy chemical examinations of the remnants. Finally, the crimes in question very often remain without direct, identifiable victims, who in the case of other crimes very often serve as a source of information about the commission of the crime(s). Finally, specifically concerning Polish criminal practice, the authorities are ill-prepared to fight this particular kind of criminality because of both a lack of adequate training and equipment. As indicated in the statistics, very few crimes against the environment are detected and properly processed, even though the levels of air pollution indicate that committing them is common and prevalent within Polish society. Also, the general public has only started to appreciate the problem and criminality of the above-described actions, which generate a considerable part of air pollution in the country, which is why the reporting rate of these crimes is still low.

In such a case, i.e., when the detection of crimes turns out to be troublesome, as the Becker model suggests, the punishment should be even more severe in order

32 Almer, C., Extending the economic model of crime to environmental offenses - and vice versa, https:// www.ethz.ch/content/dam/ethz/special-interest/mtec/cer-eth/resource-econ-dam/documents/ research/ws-and-conf/nachwuchsworkshop/Almer_Paper.pdf (accessed 15.07.2020); Faure, M., op. cit., pp. 328.

33 No extensive empirical research exists on the topic, nevertheless the conclusion is evident despite limited data. Cf: Faure, M., op.cit. pp. 320-345. 
to scare off potential perpetrators, even if the chances of getting caught are low. However, Polish environmental criminal law seems to operate according to reverse principles. First, the existing criminal regulations are either rarely employed or employed incorrectly (as is the case of the incomprehensible resignation from instigating criminal prosecution on the grounds of Art. $183 \$ 1$ CC against habitual offenders who regularly commit minor offences such as incineration of waste, even though it would not only be possible but actually desirable). Second, even if a case concerning an act against the quality of air is presented to a judge, the chances are that the final punishment will be very lenient. It has been concluded through a series of studies that judges are not willing to impose severe financial penalties for these particular crimes $^{34}$ as they consider them unimportant crimes in comparison with others (such as burglary or mugging). Judges are even less prone to consider even more severe punishment such as deprivation or limitation of liberty. ${ }^{35}$

All of the above shows that all those who violate the law when it comes to polluting the atmosphere may sleep well while under Polish jurisdiction. Not only are the chances of getting caught extremely low but also they are likely to answer only for a minor offence and suffer a minimal penalty for it. Because of the inconsequential value of these crimes, it will in all probability remain financially beneficial for the offender to keep on committing them.

\section{Final remarks and suggestions}

The above analysis not only shows that the prosecution of offences against the environment and clean air is faulty but also allows us to pinpoint the reasons why that is the case. Interestingly enough, they do not lie in the poor quality of legislation. Actually, the legal provisions currently in force in Poland regulate all conceivable manners of harmful activities directed against the atmosphere, and so they do not really require a change (maybe only for the sake of clarification of certain issues, which the author has described in his analysis). The problem lies in the way these regulations are put into practice. To rectify the current situation, following the conclusions arising from the Becker model, the Polish state should focus on two aspects related to environmental crimes.

34 Faure, M., op. cit., pp. 320-345; Meinberg V., Empirische Erkenntnisse zum Vollzug des Umweltstrafrechts, "Zeitschrift für die Gesamte Strafrechtswissenschaften" 1988, pp. 112-157; Ogus, A. and Abbot, C., op. cit., pp. 493-516.

35 Barrett, J.J., Sentencing environmental crimes under the United States sentencing guidelines: a sentencing lottery, "Environmental Law" 1992, No. 22, pp. 1421-1449. 
First, more funds should be devoted to increasing the detection rate of these crimes. The way to go about it would be to train law-enforcement agents to be more sensitive to the described issues and to educate them on how to detect, prove, and qualify the commission of such crimes. Also, a higher detection rate may be brought about by increasing general public awareness concerning the issue. If citizens are properly informed about the risks to their health that arise from the seemingly innocent activities of their neighbours, they may be more prone to report them to the authorities. Also, with the general public better informed on the issue, it will be much more difficult for those who commit the crimes described in this article to successfully plead that they were not aware of the consequences of their actions and that they cannot be held responsible for intentional crimes.

Second, assuming that the poor detection of these crimes is unavoidable due to their nature, steps should be taken to ensure that those who are sentenced for acts harming air quality are punished severely enough to deter others and also according to the criminal character of their actions and the level of social consequences. Such a goal can be achieved by increasing the lower limits of punishment possible to impose it again through proper training of prosecutors and judges so that they properly qualify specific criminal acts which they have to legally process (either as a crime or minor offence). Such training could also bring about a better appreciation of the social ramifications of the criminal acts discussed here, which could possibly lead to employing more punishment of a more adequately severe nature.

It is the author's belief that putting the above-mentioned measures into practice should result in a substantial lowering of the rate of the offences in question, as well as reducing air pollution in general. One may just hope that such measures will be adopted by the Polish state in its striving for a greener tomorrow.

\section{References}

Almer, C., Extending the economic model of crime to environmental offenses - and vice versa, https://www.ethz.ch/content/dam/ethz/special-interest/mtec/cer-eth/resource-econ-dam/documents/research/ws-and-conf/nachwuchsworkshop/Almer_Paper. pdf.

Ashraf, N. et al., Adam Smith. Behavioral economist, "Journal of Economic Perspective" 2005, Vol. 19, No. 3.

Barrett, J.J., Sentencing environmental crimes under the United States sentencing guidelines: a sentencing lottery, "Environmental Law" 1992, No. 22.

Becker, G.S., Crime and punishment: an economic approach, "Journal of Political Economy" 1968, Vol. 76, No. 2. 
Becker, G.S., Irrational behaviour and economic theory, "Journal of Political Economy" 1962, Vol. 70, No. 11-13.

Bentham, J., Introduction to the principles of morals and legislation, Kitchener 2000, https://socialsciences.mcmaster.ca/econ/ugcm/31l3/bentham/morals.pdf.

Bowles, R., Law and the economy, Oxford 1982.

Coffee, J.S., Corporate crime and punishment: a non-Chicago view of the economics of criminal sanctions, "American Criminal Law Review” 1980.

Cooter, R., Prices and sanctions, “Columbia Law Review” 1984.

Cooter, R. and Ulen, T., Law and economics, $6^{\text {th }}$ edition, Berkeley 2016.

Faure, M., Environmental crimes, in: Garoupa, N. (ed.), Criminal law and economics, Cheltenham 2009.

Gruszecka, D., Komentarz do art. 182, in: Giezek, E. (ed.), Kodeks karny. Część szczególna. Komentarz, Warszawa 2014.

Gałązka, M., Komentarz do art. 182, in: Grześkowiak, A. and Wiak, K. (eds.), Kodeks karny. Komentarz, Warszawa 2019.

Jajuga, W., in: Jajuga, W. (ed.), Zarządzanie ryzykiem, Warszawa 2007.

Królikowski, M., Komentarz do art. 183 in: Królikowski, M. and Zawłocki, R. (eds.), Kodeks karny. Część szczególna. Tom I. Komentarz do artykułów 117-221, 2017, Legalis.

Kurowski, M., Komentarz do art. 5, in: Świecki, D. (ed.), Kodeks postępowania karnego. Tom I. Komentarz, 2020, LEX.

Lachowski, J., Komentarz do art. 182, k.k., in: Konarska-Wrzosek, V. (ed.), Kodeks karny. Komentarz, 2018, LEX.

Miceli, T., Optimal prosecution of defendants whose guilt is uncertain, "Journal of Law, Economics and Organisation" 1990, No. 6.

Meinberg, V., Empirische Erkenntnisse zum Vollzug des Umweltstrafrechts, "Zeitschrift für die Gesamte Strafrechtswissenschaften” 1988.

Ogus, A. and Abbot, C., Pollution and penalties, in: Swanson, T. (ed.), An introduction to the law and economics of environmental policy: issues in institutional design, Amsterdam 2002.

Polinsky, M. and Shavell, S., The economic theory of public enforcement of law, "Journal of Economic Literature" 2000, No. 38.

Posner, R., An economic theory of the criminal law, "Columbia Law Review" 1985, No. 85.

Posner, R., Frontiers of legal theory, Harvard 2004.

Posner, R., Optimal sentences for white-collar criminals, "American Criminal Law Review" 1980, Vol. 17.

Radecki, W., Ochrona środowiska w nowym prawie karnym, cz. II: Prawnokarna ochrona przed zanieczyszczeniami, odpadami i promieniowaniem, "Monitor Prawniczy” 1998, No. 1, Legalis.

Radecki, W., Komentarz do art. 182 k.k., in: Górniok, O. (ed.), Kodeks karny. Komentarz, Warszawa 2005. 
Radecki, W., Komentarz do art. 191, in: Radecki, W. (ed), Ustawa o odpadach. Komentarz, Warszawa 2012.

Shavell, S., Criminal law and the optimal use of non-monetary sanctions as a deterrent, "Columbia Law Review" 1985, No. 85.

Skogh, G., A note on gary becker's crime and punishment: an economic approach, "Swedish Journal of Economics" 1973, Vol. 75.

Skogh, G. and Stuart, C., An economic analysis of crime rates, punishment and the social consequences of crime, "Public Choice" 1982, No. 38.

Stigler, G., The optimum enforcement of laws, "Journal of Political Economy" 1970, Vol. 78, No. 3.

Zoll, A., Komentarz do art. 182, in: Wróbel, W. and Zoll, A. (eds.), Kodeks karny. Część ogólna. Tom I. Część I. Komentarz do art. 1-52, 2016, LEX.

\section{CITATION}

PODHALICZ, M., Protecting the right to clean air through criminal law: a perspective from economic law analysis and the case of Poland, "Acta Iuris Stetinensis" 2020, No. 1 (Vol. 29), 147-164, DOI: 10.18276/ais.2020.29-10. 